\title{
Organic Matter and the Absorption of Cadmium in Organic Cacao Almonds (Theobroma cacao L.), Leoncio Prado-Huánuco
}

\author{
Nelino Florida ${ }^{*}$, Shilthon L Claudio ${ }^{1}$, Cesar Augusto Gozme Sulca ${ }^{1}$ and Raul G Bernal ${ }^{2}$ \\ ${ }^{1}$ Universidad Nacional Agraria de la Selva, Peru \\ ${ }^{2}$ Asociación de Productores Cacao Alto Huallaga, Peru
}

Submission: April 01, 2019; Published: April 10, 2019

"Corresponding author: Nelino Florida, Universidad Nacional Agraria de la Selva, Facultad de Recursos Naturales Renovables, Av Universitaria Km 1,5 carretera Tingo María -Huánuco, Peru

\begin{abstract}
Soil quality has an important influence on the dynamics of cadmium by the cacao plant (Theobroma cacao L.), in particular the organic matter (MO) present in the soil. Therefore, the objective was to measure the influence of soil MO on the levels of cadmium absorption in cocoa almonds CCN-51 in Leoncio Prado - Huánuco province. ADCA design was used, for which 20 agricultural plots were selected from the members of Cooperative Cacao Alto Huallaga, who complied with all organic production standards and techniques. 20 samples of soils and almonds were analyzed. The results show that the average content of the MO was $2,3 \%$, the cadmium available in the soil was $0,32 \mu \mathrm{g} \mathrm{g}^{-1}$ and the content of cadmium in the almonds yielded $0,98 \mathrm{\mu g} \mathrm{g}^{-1}$. The research concludes that the values of cadmium in almonds are above the maximum level allowed by the European Union and a non-significant negative correlation was found between soil MO and the content of cadmium in soil and cocoa almonds, finding a non-significant dependence of cadmium in almonds, with respect to soil MO.
\end{abstract}

Keywords: Cadmium in the soil; Cadmium in almonds; Cocoa CCN-51; Soil organic matter

\section{Introduction}

Cocoa (Theobroma Cacao L.) is one of the crops of great economic importance for Peru, Huánuco contributes with it $6 \%$ of the national production, occupies the fifth place in the list (San Martín with 43\%, Junín with the 18\%, Cusco with 9\%, Ucayali with $8 \%$ ). In addition, the Ministry of Agriculture and IrrigationMINAGRI [1], reports the behavior of the national production of cocoa between 2009 and 2015, it shows an average annual increase of $15.5 \%$, so that, of 36.8 thousand tons produced in in 2009 , it rises to 87.3 thousand tons in 2015 (137.2\% increase), reaching an area of 121.3 thousand hectares with an average yield of $720 \mathrm{~kg} / \mathrm{ha}$.

However, the European Union (EU) approved the new regulation on maximum limits of cadmium in cocoa derivatives through Regulation No. 488/2014 which comes into force as of January 1, 2019 throughout the EU, the norm considered as the maximum content of cadmium in various cocoa products in a range of 0.10 to $0.80 \mu \mathrm{g} \mathrm{g}^{-1}$ [2] and exports of cocoa beans from Peru, highlights the EU which concentrates $76 \%$ of total exports [1]. Therefore, this becomes a national concern, since it is our main target market, making it necessary to investigate to generate basic knowledge that allows generating technologies to reduce the levels of $\mathrm{Cd}^{2+}$ in cocoa beans.

It is necessary to point out that in natural conditions there is averages of $<1 \mu \mathrm{g} \mathrm{g}^{-1} \mathrm{of} \mathrm{Cd}^{2+}$ in the soil solution and most researchers consider that their absorption in almonds is influenced by some soil parameters [3]. The type of soil has an important influence on the availability and absorption by the plant, among the soil parameters that correlate with the concentration of heavy metals, as the cadmium are $\mathrm{pH}$, texture, $\mathrm{OM}$ and $\mathrm{Zn}$ and $\mathrm{P}$ levels $[4,5]$. Therefore, the objective of the work is to evaluate the influence of $\mathrm{OM}$ on the levels of $\mathrm{Cd}^{2+}$ in the soil and on organic cocoa almonds CCN-51 (Theobroma cacao.), in the Leoncio Prado - Huánuco province.

\section{Materials and Methods}

\section{Study area}

The investigation was developed in the last quarter of 2017, in the province of Leoncio Prado, located in the department of Huánuco-Peru, The climatic conditions in which this project was developed are: average annual precipitation of $3,428.8 \mathrm{~mm}$, 
average annual temperature of $24.5{ }^{\circ} \mathrm{C}$ and an average relative humidity of $77 \%$, according to the weather station José Abelardo Quiñones (Universidad Nacional Agraria de la Selva). It presents bimodal season; the highest rainfall occurs between the months of September to April and the dry season covers from the months May to August. The characteristics of the evaluated plots correspond to cocoa plantations of Clone CCN-51 with an approximation of 7 years of production, with organic certification and with an average production of $500 \mathrm{~kg} / \mathrm{ha}$ (Table 1 ).

Table 1: Owners and place of extraction of soil and almond samples.

\begin{tabular}{|c|c|c|c|}
\hline Sample (Code) & Producer & Location & Clone \\
\hline PITEIS 01 & Clorinda Jesus Ruiz & New town & $\mathrm{CCN}-51$ \\
\hline PITEIS 02 & Cinthia Kiani Isidro Ushiñagua & Big Castle & $\mathrm{CCN}-51$ \\
\hline PITEIS 03 & Leoncio Condezo Luciano & Luyando & CCN-51 \\
\hline PITEIS 04 & Carlos Gómez Bernal & Appearance & $\mathrm{CCN}-51$ \\
\hline PITEIS 05 & Margot Álvarez Salas & Big Castle & $\mathrm{CCN}-51$ \\
\hline PITEIS 06 & Mendis Paredes Arce & Big Castle & $\mathrm{CCN}-51$ \\
\hline PITEIS 07 & Augusto Ascencio Bedoya & New town & $\mathrm{CCN}-51$ \\
\hline PITEIS 08 & Gabriel Borrovich Rivera & Luyando & $\mathrm{CCN}-51$ \\
\hline PITEIS 09 & Maximiliano Gamarra Trujillo & Luyando & $\mathrm{CCN}-51$ \\
\hline PITEIS 10 & Daría Solís Hermosilla & New town & $\mathrm{CCN}-51$ \\
\hline PITEIS 11 & Juan Luis Ramírez Morales & José Crespo y Castillo & $\mathrm{CCN}-51$ \\
\hline PITEIS 12 & Jorge David Salazar Lino & Luyando & $\mathrm{CCN}-51$ \\
\hline PITEIS 13 & José Natividad Pérez & Luyando & $\mathrm{CCN}-51$ \\
\hline PITEIS 14 & Arnulfo Gamarra Trujillo & Luyando & $\mathrm{CCN}-51$ \\
\hline PITEIS 15 & María Barrueta Cajas & New town & $\mathrm{CCN}-51$ \\
\hline PITEIS 16 & Lucía Espinoza Sabino & Mariano Dámaso Beraún & $\mathrm{CCN}-51$ \\
\hline PITEIS 17 & Hernán Serrano Domínguez & New Progress & $\mathrm{CCN}-51$ \\
\hline PITEIS 18 & Fernando Tenazoa Jesús & Irazola & CCN-51 \\
\hline PITEIS 19 & Segundo Pinedo Ortega & New Progress & $\mathrm{CCN}-51$ \\
\hline PITEIS 20 & Rubén Delgado Paredez & Irazola & $\mathrm{CCN}-51$ \\
\hline
\end{tabular}

\section{Soil sampling}

Soil sampling followed the criteria of the methodology proposed by the USDA, extracting a composite sample (from 20 subsamples) per hectare, to a depth of $0-20 \mathrm{~cm}$ and be submitted to the analysis of characterization in the analysis laboratory of Soils of the National Agrarian University of the Selva (UNAS). The chemical analysis of cadmium requires milling the sample in porcelain mortar and passing through a $150 \mu \mathrm{m}$ sieve, then applying the ISO 11466-Soil quality methodology, which consists of:

a. Weigh approximately $3 \mathrm{~g}$ of the soil sub-sample with an accuracy of $0.001 \mathrm{~g}$ in the $250 \mathrm{ml}$ reaction balloon.

b. Moisten the soil with $0.5-1 \mathrm{ml}$ of distilled or deionized water and add stirring, $21 \mathrm{ml}$ of hydrochloric acid followed by $7 \mathrm{ml}$ of nitric acid, dropwise if necessary, to avoid foam production.

c. Add $15 \mathrm{ml}$ of nitric acid to the reaction balloon and let stand for $16 \mathrm{~h}$. and cover with a clock moon.

d. Slowly increase the temperature of the reaction mixture to reflux conditions and keep it for $2 \mathrm{~h}$. e. After 2 hours have elapsed, let the sample cool down.

f. Then decant the supernatant extract on whatman 40 filter paper, collect the filtrate in a $100 \mathrm{ml}$ graduated flask. Pass all the extract through the filter paper and wash the insoluble residue with the minimum volume of nitric acid.

g. The extract prepared in this way is suitable for the determination of metals by Atomic Absorption Spectrophotometry.

For soil $\mathrm{pH}$ analysis the potentiometer method was applied with a soil/water ratio of 1 : 1 . For the analysis of cadmium in cocoa beans, the following protocol was applied:

a. Remove the mucilage from the samples of fresh cocoa, and then dry in the oven at $75^{\circ} \mathrm{C}$ for 24 hours.

b. Descascarillar the almonds with the help of a razor of suitable and sterile material that does not contaminate the samples.

c. Crush the samples, from this crushed $0.5 \mathrm{~g}$ will be taken.

d. Take $0.5 \mathrm{~g}$ of the sample and undergo a perchloric nitric acid solution, in an extract ratio of 1: 4, 4 (according to Carillo, 
2003, cited by MITE, 2010). The ground vegetable tissues should be mixed with $\mathrm{HNO}_{3}(8 \mathrm{ml})$ and $\mathrm{HClO}_{4}(2 \mathrm{~mm})$ for one hour and heated at $180{ }^{\circ} \mathrm{C}$ for 90 minutes until complete digestion.

e. Then filter this extract in $50 \mathrm{ml}$ balloon and bring to volume with deionized water.

f. The extract obtained can be read in the spectrometry equipment [6].

\section{Statistical analysis}

The design used is completely randomized DCA where the treatment is constituted by CCN-51 cocoa plots, with sample size $\mathrm{n}=20$ (soil and almond samples). The data of OM levels and the $\mathrm{Cd}^{2+}$ contents of the soil and plant were subjected to Pearson correlation analysis $(\mathrm{p}<0.05)$.

\section{Results and Discussion}

Table 2: Content of $\mathrm{MO}$ and $\mathrm{Cd}$ in the soil.

\begin{tabular}{|c|c|c|}
\hline Sample (Code) & MO (\%) & $\mathrm{Cd}^{2+}\left(\mu \mathrm{g} \mathrm{g}^{-1}\right)$ \\
\hline PITEIS 01 & 1,18 & 0,41 \\
\hline PITEIS 02 & 1,76 & 0,29 \\
\hline PITEIS 03 & 1,29 & 0,37 \\
\hline PITEIS 04 & 1,12 & 0,64 \\
\hline PITEIS 05 & 2,61 & 0,17 \\
\hline PITEIS 06 & 2,07 & 0,82 \\
\hline PITEIS 07 & 1,47 & 0,16 \\
\hline PITEIS 08 & 1,97 & 0,15 \\
\hline PITEIS 09 & 3,51 & 0,10 \\
\hline PITEIS 10 & 2,76 & 0,21 \\
\hline PITEIS 11 & 3,10 & 0,02 \\
\hline PITEIS 12 & 3,05 & 0,89 \\
\hline PITEIS 13 & 2,15 & 0,91 \\
\hline PITEIS 14 & 3,59 & 0,07 \\
\hline PITEIS 15 & 2,84 & 0,06 \\
\hline PITEIS 16 & 4,14 & 0,40 \\
\hline PITEIS 17 & 1,54 & 0,23 \\
\hline PITEIS 18 & 1,15 & 0,18 \\
\hline PITEIS 19 & 3,07 & 0,12 \\
\hline PITEIS 20 & 1,54 & 0,13 \\
\hline MEDIA & 2,30 & 0,32 \\
\hline SEM & $\pm 0,21$ & $\pm 0,063$ \\
\hline \multicolumn{3}{|c|}{ SEM = Standard Error of the Mean } \\
\hline
\end{tabular}

The average value of the $\mathrm{OM}$ is $2.3 \%$ (Table 2), which corresponds to a medium level [7], which are typical values of the tropical part and in particular in soils where cocoa is grown. This content contrasts with Arévalo et al. [5] in a study of the main cocoa producing areas of Peru, reported similar values, contents that vary from $2-4 \%$ were found in Tumbes (Tumbes), Piura, Cajamarca (Jaén), Amazonas and San Martín (Bellavista,
El Dorado, Huallaga and Mariscal Cáceres), Huánuco and Junín. However, they also found high concentrations $>4 \%$ in the Cuzco region; while low contents were located in Tumbes (Zarumilla) and San Martín (Tocache).

Within the scope of our research there are some reports that warn a similar content of MOS in soils with cocoa production. Huamani et al. [4], in a research located between Huánuco and Ucayali, reports an average MOS content of $2.58 \%$ and consider this value as an adequate condition for the development of the cocoa crop. Also, the results of Tantalean and Huauya [8], in Jacintillo and Ramal de Aspuzana, found higher values for residual and alluvial soils with variations of 3 to $4 \%$, however, these values are considered as average contents [7]. Therefore, the average value found represents adequate and typical values of the areas destined for the production of cocoa in the province of Leoncio Prado.

The values of $\mathrm{Cd}^{2+}$ found in this investigation, presents an average of $0.32 \mu \mathrm{g} \mathrm{g}^{-1}$ (Table 2), categorized as low level of $\mathrm{Cd}^{2+}$ by the most important standards such as the Environmental Agency of the United States of North America (USEPA) established a critical level of $0.43 \mu \mathrm{g} \mathrm{g}^{-1}$ of total cadmium in agricultural soils [9]. Also, the EU European Union, through the Kelley directive, indicates that typical values in uncontaminated cadmium soils are between 0 and $1 \mu \mathrm{g} \mathrm{g}^{-1}[10]$ and our regulation establishes $1,4 \mu \mathrm{g}$ $\mathrm{g}^{-1}$ for agricultural land [11].

However, when compared with other local investigations, it is lower than that reported in this same area by Huamaní et al. [4], average cadmium values of $0.53 \mu \mathrm{g} \mathrm{g}^{-1}$ and considers its results as a low content. However, Tantalean and Huauya [8] found values of 0.90 for residual soils and $3.68 \mu \mathrm{g} \mathrm{g}^{-1}$ for an alluvial soil, the latter are high values and is considered as a soil contaminated by $\mathrm{Cd}^{2+}$, according to our regulations and the aforementioned international standards. In addition, there are references at the national level such as Crozier et al. [12], who found higher values of $\mathrm{Cd}^{2+}$ in the North Zone $\left(0.79 \mu \mathrm{g} \mathrm{g}^{-1}\right)$ and lower in the Central Zone $\left(0.68 \mu \mathrm{g} \mathrm{g}^{-1}\right)$ and South $\left(0.46 \mu \mathrm{g} \mathrm{g}^{-1}\right)$ of Peru. On the contrary, the results of Arévalo et al. [5], reports that cadmium has been the least common metal in the sampled soils. Null values of $0.00 \mu \mathrm{g}$ $\mathrm{g}^{-1}$ found in Cajamarca (San Ignacio), San Martin (El Dorado and Tocache), Huánuco and Cuzco.

The correlation analysis (Figure 1) between $\mathrm{MO}$ and $\mathrm{Cd}^{2+}$ in the evaluated soils shows statistically a nonsignificant negative correlation, with a coefficient of determination of $R^{2}=0.026$; According to the curve of the mathematical function, a slight decreasing tendency of cadmium in the soil can be observed, as MO increases. This behavior is corroborated by Tantalean and Huauya [8], they found a negative tendency between the presence of cadmium with the increase of OM. However, it is contrary to that reported by Arévalo et al. [5], since in their results they observed statistically significant differences $(\mathrm{p}<0.05)$ and a significant positive correlation for MOS, with $\mathrm{R}^{2}=0.33$. 


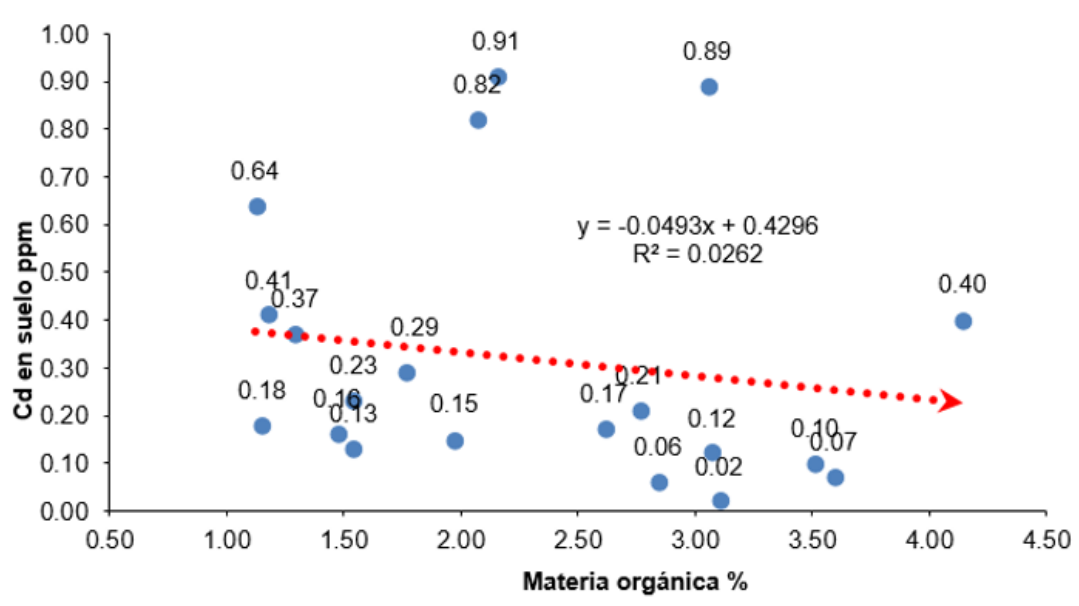

Figure 1: Correlation between organic matter and $\mathrm{Cd}^{2+}$ of the soil.

According to the correlation analysis (Figure 1), we observed that the MO does not correlate significantly with the $\mathrm{Cd}^{2+}$, it can be explained taking into account that the availability of $\mathrm{Cd}^{2+}$ in the soil can be influenced by other parameters, within the main attributes that are Related to the mobility and availability of heavy metals in the soil are $\mathrm{pH}, \mathrm{Fe}, \mathrm{Mn}$ and $\mathrm{Zn}$ oxides and clay content $[4,5,13]$.
The organic matter of general form influences in the properties of the floor that contribute to the quality of the soils like the apparent densidad, structure, acidity, availability of nutrients and decrease of the availability of heavy metals $[14,15]$. This behavior is also pointed out by Sauve et al. [16], specifies that heavy metals are a function of $\mathrm{pH}$, clay content, organic matter, cation exchange capacity and other soil attributes.

Table 3: OM content of soil and cadmium in cocoa almonds.

\begin{tabular}{|c|c|c|}
\hline Sample (Code) & MO (\%) & Cd in Almond ( $\mu \mathrm{g} g-1)$ \\
\hline PITEIS 01 & 1,18 & 1,37 \\
\hline PITEIS 02 & 1,76 & 0,61 \\
\hline PITEIS 03 & 1,29 & 0,38 \\
\hline PITEIS 04 & 1,12 & 1,25 \\
\hline PITEIS 05 & 2,61 & 0,52 \\
\hline PITEIS 06 & 2,07 & 0,18 \\
\hline PITEIS 07 & 1,47 & 0,91 \\
\hline PITEIS 08 & 1,97 & 0,30 \\
\hline PITEIS 09 & 3,51 & 0,30 \\
\hline PITEIS 10 & 2,76 & 1,72 \\
\hline PITEIS 11 & 3,10 & 0,43 \\
\hline PITEIS 12 & 3,05 & 0,20 \\
\hline PITEIS 13 & 2,15 & 6,70 \\
\hline PITEIS 14 & 3,59 & 0,18 \\
\hline PITEIS 15 & 2,84 & 0,70 \\
\hline PITEIS 16 & 4,14 & 1,52 \\
\hline PITEIS 17 & 1,54 & 0,58 \\
\hline PITEIS 18 & 1,15 & 0,85 \\
\hline PITEIS 19 & 3,07 & 0,45 \\
\hline PITEIS 20 & 1,54 & 0,53 \\
\hline Media & 2,3 & 0,98 \\
\hline SEM & $\pm 0,21$ & $\pm 0,32$ \\
\hline \multicolumn{3}{|c|}{ SEM = Standard Error of the Mean } \\
\hline
\end{tabular}


In Table 3, the cadmium content of cocoa almond samples is shown; whose average content is $0.98 \mu \mathrm{g} \mathrm{g}^{-1}$; this level exceeds the maximum permissible limit of the EU (Regulation No. 488/2014) which establishes the maximum content for cocoa derivatives in a range of 0.10 to $0.80 \mu \mathrm{g} \mathrm{g}^{-1}$ [2]. These high cadmium contents in almonds, for this investigation is not related to MO, because the correlations found are not statistically significant. Therefore, we attribute this high level of $\mathrm{Cd}^{2+}$ fundamentally to other soil characteristics; as a level of $\mathrm{pH}, \mathrm{CIC}$, oxides and the amount of clay present $[4,5,15]$.

In addition, Tantalean and Huauya [8], explain that the high concentrations of total cadmium in almonds, may be due to the high concentrations of cadmium available in the soil, total cadmium in root, stems, leaves, and their mobility in the crop. Finally, Isaura [17], says that organic matter acts actively in the adsorption of cadmium, and this activity is defined not only by the amount in which it is found in the soil environment, but also, and decisively, by its composition. Even that, for our case, this attribute shows a non-significant action.
There are local investigations that agree with our results, such as Tantalean and Huauya [8], which report cadmium content in almonds from plots located in residual soil of $0.84 \mu \mathrm{g} \mathrm{g}^{-1}$, and in the alluvial soil of $1.08 \mu \mathrm{g} \mathrm{g}^{-1}$, even higher values, reports Lanza et al. [18], $\mathrm{Cd}^{2+}$ concentrations located in a range between 0.95 and $2.09 \mu \mathrm{g} \mathrm{g}^{-1}$. However, these results are high compared to what was reported by Zambrano [19], in the city of light of America-Ecuador, their results showed maximum levels of $0.41 \mu \mathrm{g} \mathrm{g}^{-1}$ and minimum levels of $0.31 \mu \mathrm{g} \mathrm{g}^{-1}$ in $\mathrm{CCN}-51$ with different drying method. Likewise, Sofia and Pablo [20], in Esmeraldas-Ecuador, found an average of cadmium in cocoa almonds of $0.35 \mu \mathrm{g} \mathrm{g}^{-1}$, a value lower than our results.

In the regression equation between soil organic matter and cadmium in almonds (Figure 2), the trend line that best fits the evaluated values is linear $(y=-0.1106 x+1.2378)$ with a coefficient of determination of $\mathrm{R}^{2}=0.0052$; According to the curve of the mathematical function, a slight decreasing tendency of the cadmium in the almonds can be observed, as the organic matter in the soil increases.

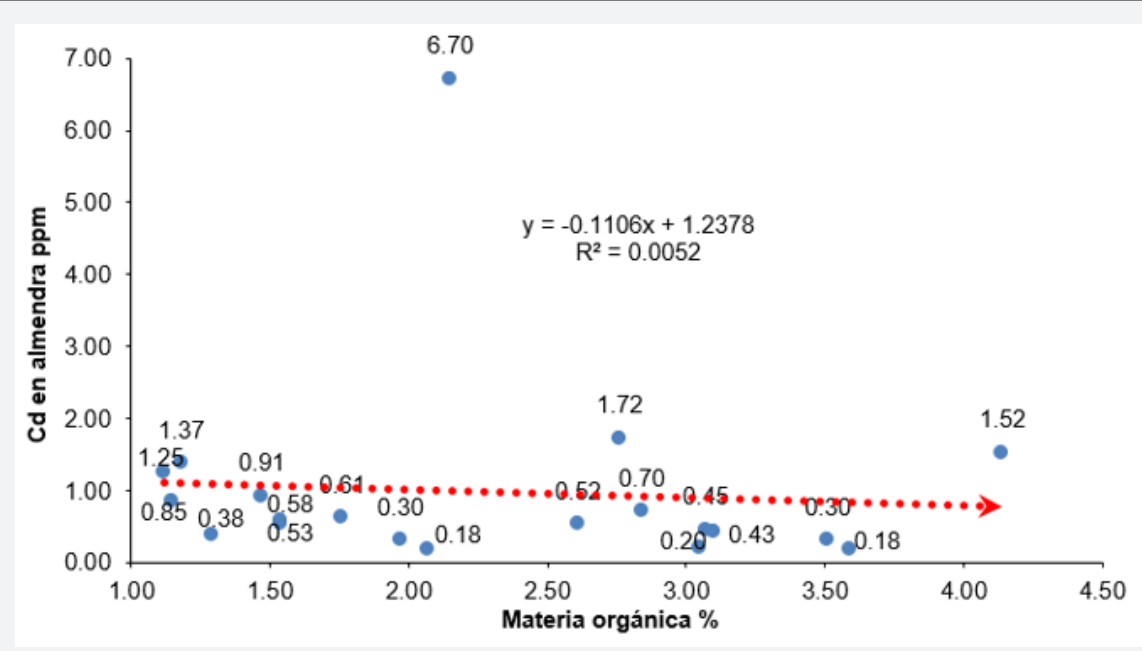

Figure 2: Correlation between organic matter and $\mathrm{Cd}$ in almonds.

Finally, our results show a low content of $\mathrm{Cd}^{2+}$ in the soils and high in almonds and the correlation analysis shows no significance between the MO and the $\mathrm{Cd}^{2+}$, that is, the OM does not explain or significantly influence the high levels found in the almonds. Therefore, recent studies of $\mathrm{Cd}^{2+}$ in soils and almonds, which warn of high levels of heavy metals $[4,5,8,12]$ and that would affect consumption and exports as of January 2019, have not been resolved clearly. Therefore, it is necessary to continue research to generate basic knowledge that allows finding technologies to reduce the levels of $\mathrm{Cd}^{2+}$ in cocoa beans.

\section{Conclusion}

The average content of soil organic matter was $2.3 \%$, which represents an average level in the cocoa plots [7] and the average level of cadmium available in the soil was $0.32 \mu \mathrm{g} \mathrm{g}^{-1}$, considered low for USEPA [9], the Kelley directive of the European Union and the ECA of Peru. The average content of cadmium in cocoa beans in the samples analyzed was $0.98 \mu \mathrm{g} \mathrm{g}^{-1}$, higher than the maximum level allowed by the European Union (Regulation No. 488/2014). Finally, a non-significant negative correlation was found between the $\mathrm{MO}$ and $\mathrm{Cd}^{2+}$ in the soils evaluated with $\mathrm{R}^{2}=0.0026$ and a nonsignificant negative correlation between the soil MO and the cadmium content in the cocoa almonds, with $\mathrm{R}^{2}=0.052$ that is to say, as the $\mathrm{OM}$ of the soil increases, the cadmium tends to decrease in the soil and cocoa almonds.

\section{References}

1. MINAGRI (2016) Estudio del CACAO en el Perú y en el Mundo; Situación Actual y Perspectivas en el Mercado Nacional e Internacional al 20155. MINAGRI-DGPA-DEEIA, pp. 86.

2. Jiménez TCS (2015) Global legal status of cadmium in cocoa (Theobroma cacao): fantasy or reality. Production + Clean 10(1): 89104. 
3. Madeddu R (2005) Estudio de la influencia del cadmio sobre el medioambiente y el organismo humano. University of Granada, p. 159.

4. Humani HA, Huauya MA, Mansilla LG, Florida RN, Neira GM (2012) Presence of heavy metals in the cultivation of organic cocoa (Theobroma cacao L.). Acta Agronomica 61(4): 339-344.

5. Arévalo GE, Meyier E, Obando C, Zúñiga CL, Cesar O, et al. (2016) Heavy metals in soils of cocoa plantations (Theobroma cacao 1.) in three regions of peru. Ecología Aplicada 15(2): 81-89.

6. Sayvet VB (2013) Guía metodológica para el muestreo y detección de cadmio en suelos, agua, fertilizantes, almendras de cacao y productos derivados, Lima, p. 76.

7. Secretaría de Agricultura, Ganadería, Desarrollo Rural, Pesca y Alimentación SAGARPA (2012) Subíndice de Uso Sustentable del Suelo - Metodología de Cálculo. Componente: Línea de Base del Programa de Sustentabilidad de los Recursos Naturales. p. 68.

8. Tantalean PE, Huauya RM (2017) Distribución del contenido de cadmio en los diferentes órganos del cacao CCN-51 en suelo aluvial y residual en las localidades de Jacintillo y Ramal de Aspuzana. Rev of investgacion agro-produccion sustenable 1(2): 69-78.

9. United States Environmental Protection Agency USEPA (2002) Supplemental guidance for developing soil screening levels for superfund sites. pp. 187.

10. Acevedo E, Carrasco M, Leon O, Silva P, Castillo G, et al. (2005) Report on quality criteria for agricultural land. Agricultural and Livestock Service, Chile. pp. 205.

11. MINAM (2017) Environmental Quality Standards (ECA) approved for Soil Supreme Decree N 011-2017-MINAM. p. 12.

12. Crozier J (2012) Heavy metals in Cocoa. International Workshop on Possible EU regulations on cadmium in cocoa and chocolate products.
Nature and Food Quality in the Netherlands (LNV), the European Cocoa Association (ECA) and CAOBISCO. p. 16.

13. Degryse F, Smolders E, Parker DR (2009) Partitioning of metals (Cd, $\mathrm{Co}, \mathrm{Cu}, \mathrm{Ni}, \mathrm{Pb}, \mathrm{Zn}$ ) in soils: concepts, methodologies, prediction and applications - A review. European Journal of Soil Science 60(4): 590612.

14. Bot, Benítez (2005) The importance of soil organic matter key to drought-resistant soil and sustained crop production. FAO soils bulletin, p. 80 .

15. Alloway BJ (2013) Heavy metals in Soils: Trace Metals and Metallloids in Soils and their Bioavailability, ( $3^{\text {rd }}$ edn). Environmental Pollution.

16. Sauve S, Norvell WA, Mcbride M, Hendershot W (2000) Speciation and complexation of cadmium in extracted soil solutions. Environ Sci Technol 34(2): 291-296.

17. Isaura R (2010) Capacidad de amortiguación de la contaminación por plomo y por cadmio en suelos de la comunidad de Madrid. Universidad Complutense de Madrid. Departamento de Edafología. Madrid, España.

18. Lanza JG, Churion PC, Liendo NJ, Lopez VH (2016) Evaluation of the content of heavy metals in cocoa (Theobroma cacao l.) Of santa bárbara del zulia, Venezuela. Know, Universidad de Oriente, Venezuela 28(1): 106-115.

19. Zambrano VE (2017) Evaluation of cadmium content in two varieties of cocoa (Theobroma cacao L.) considering different drying methods in the locality of luz de america. National University of the Armed ForcesEcuador. p. 61.

20. Sofia A, Pablo P (2013) Determination of Cadmium in the Cocoa Almond (Theobroma cacao) of five farms located on the San Domingo - Esmeralda route. Pontifica Universidad del Ecuador, Faculty of exact sciences and nature, Ecuador. p. 81.

\begin{tabular}{|l|}
\hline \multicolumn{1}{|c|}{ Your next submission with Juniper Publishers } \\
will reach you the below assets \\
- Quality Editorial service \\
- Swift Peer Review \\
- Reprints availability \\
- E-prints Service \\
- Manuscript Podcast for convenient understanding \\
- Global attainment for your research \\
- Manuscript accessibility in different formats \\
( Pdf, E-pub, Full Text, Audio) \\
- Unceasing customer service \\
Track the below URL for one-step submission \\
https://juniperpublishers.com/online-submission.php \\
\hline
\end{tabular}

